First in Line 



\section{First in Line}

\section{Tracing Our Ape Ancestry}

Tom Gundling 
Copyright (C) 2005 by Yale University.

All rights reserved.

This book may not be reproduced, in whole or in part, including illustrations, in any form (beyond that copying permitted by Sections 107 and 108 of the U.S. Copyright Law and except by reviewers for the public press), without written permission from the publishers.

Set in Minion type by Keystone Typesetting, Inc.

Printed in the United States of America.

Library of Congress Cataloging-in-Publication Data

Gundling, Tom, 1962-

First in line : tracing our ape ancestry / Tom Gundling.

p. $\mathrm{cm}$.

Includes bibliographical references and index.

ISBN 0-300-10414-6 (cloth : alk. paper)

1. Human beings-Origin. 2. Fossil hominids. 3. Australopithecines.

4. Paleoanthropology. I. Title.

GN281.G86 2005

$569.9-\mathrm{dc} 22$

2004059897

A catalogue record for this book is available from the British Library.

The paper in this book meets the guidelines for permanence and durability of the Committee on Production Guidelines for Book Longevity of the Council on Library Resources.

$109 \begin{array}{llllllll}10 & 7 & 6 & 5 & 4 & 3 & 2 & 1\end{array}$ 
For Dr. Frank Spencer, whom I never met in person but wish I had 
